\title{
Introduction, establishment and expansion of the Pacific oyster Crassostrea gigas in the Oosterschelde (SW Netherlands)
}

\author{
A. C. Smaal · B. J. Kater · J. Wijsman
}

Received: 20 February 2008 / Revised: 20 June 2008 / Accepted: 4 August 2008 / Published online: 31 October 2008

(c) The Author(s) 2008. This article is published with open access at Springerlink.com

\begin{abstract}
The Pacific oyster Crassostrea gigas was first introduced as an exotic species by oyster farmers in 1964 in the Oosterschelde estuary (SW Netherlands). The initial phase is not well documented but first natural spatfall was recorded in 1975. Excessive spatfall occurred in 1976 and this is considered the start of the expansion phase of the wild oysters. Oyster beds in intertidal and subtidal areas of the Oosterschelde estuary have been growing since. The development in the intertidal area has been reconstructed by using aerial photography, validated by ground truth in 2000-2002. In the subtidal areas extensive oyster beds have been detected by using side scan sonar; on hard substrates along the dikes coverage with oysters up to $90 \%$ locally has been recorded by scuba diving surveys. Expansion has also occurred into adjacent water bodies including the Wadden Sea. By forming resistant reefs the oysters induce structural changes in the ecosystem. It is concluded that bed area is still expanding while decrease of the fraction live animals may indicate adjustment of the stock size to the local conditions.
\end{abstract}

Keywords Pacific oysters $\cdot$ Biomass $\cdot$ Bed area . Invasion · Adjustment

Communicated by K. Reise.

A. C. Smaal $(\bowtie) \cdot$ B. J. Kater · J. Wijsman

IMARES, P.O. Box 77, 4400 AB Yerseke, The Netherlands

e-mail: aad.smaal@wur.nl

B. J. Kater

Alkyon, P.O. Box 248, 8300 AE Emmeloord, The Netherlands

\section{Introduction}

The Pacific oyster Crassostrea gigas has been introduced in 1964 in the Oosterschelde estuary, SW Netherlands, for aquaculture purposes. In the severe winter 1962/1963 the existing culture stock of flat oysters Ostrea edulis suffered from mass mortality and the extensive traditional flat oyster culture in this area faced an economic disaster. Indeed out of 120 million oysters only 4 million survived and more than $90 \%$ of the oyster companies stopped their business (Gmelich-Meyling-van Hemert 2004). To maintain the culture activities Pacific oysters were introduced at an experimental scale from British Columbia (Canada) (Drinkwaard 1999a; Wolff 2005). The experimental introduction of various strains of Pacific oysters was considered successful, and some farmers started with pacific oyster culture (Drinkwaard 1999a).The first signs of successful recruitment of Pacific oysters in the Oosterschelde are reported by Drinkwaard (1999a) for 1975, a year with relatively high summer temperatures. In the following summer of 1976, water temperatures over $20^{\circ} \mathrm{C}$ prolonged for over a month and high recruitment success was recorded. Warm summers of 1982 and 1986 were again followed by large Pacific oyster spatfall. As shown by Diederich et al. (2004) warm summers are considered as the main factor for excessive Pacific oyster spatfall. It is likely that proliferation of the Pacific oyster along Dutch coastal waters started in the mid seventies, promoted by increasing use of the species for aquaculture in the Oosterschelde, and the more frequent occurrence of warm summers.

Reise et al. (2006) describe the development of invasive populations in subsequent phases of invasion. It starts with (1) arrival, then there is (2) the establishment phase with a small-sized population of colonists, in (3) the expansion phase: population size increases rapidly till a maximum is 
reached, followed by (4) the adjustment phase when the population decreases to an equilibrium size.

For the Oosterschelde the development is described on the basis of a reconstruction by aerial photographs and ground truth of contours and biomass (Kater and Baars 2004; RIVO/Imares reports).

Further proliferation has been documented for the Dutch Wadden Sea (Wolff 2005; Smaal et al. 2005), the Niedersachsen Wadden Sea (Wehrmann et al. 2000), and the Schleswig-Holstein parts of the German Wadden Sea (Reise 1998; Nehls et al. 2006).

The aim of this paper is (1) to document the arrival and the establishment of the oysters, (2) to describe the expansion phase, and (3) to quantify the actual size of the oyster population of the Oosterschelde. We hypothesize that the characteristics of the oysters as bivalve filter feeders in combination with the ability to form resistant structures result in a positive feedback for further expansion. The question is if and as to how far adjustment of the population will occur and how this can be estimated.

\section{Materials and methods}

Study area

The Oosterschelde estuary (SW Netherlands) is a tidal system of $350 \mathrm{~km}^{2}$ with intertidal flats $\left(110 \mathrm{~km}^{2}\right)$, deep gullies, artificial rocky shores for dike defense, and shallow water areas (Fig. 1). A storm surge barrier between the estuary and the North Sea protects the area from flooding but is normally open, allowing a tidal range varying from $2.5 \mathrm{~m}$ at the entrance to $4 \mathrm{~m}$ at the eastern boundaries. The system has an average freshwater load of $25 \mathrm{~m}^{3} / \mathrm{s}$ and is mesotrophic with an average salinity of $30 \mathrm{ppt}$; there are no untreated waste water discharges (Nienhuis and Smaal 1994).

The area is important as nature conservation area and of particular relevance for wader birds such as the Oystercatcher that overwinters in large numbers. The area is extensively used for shellfish bottom culture and cockle fishery. There are 1,550 ha oyster culture plots, all located in the eastern part (Fig. 1)

Estimation of oyster bed area

\section{Intertidal beds}

Oyster bed contours have been registered by walking around oyster beds at low tide and identifying the contours with GPS. At each bend in the contour a waypoint was registered. Contours were used to construct maps of oyster beds in GIS. An oyster bed was defined in a similar way as mussel beds (CWSS 2007), as a cluster of oysters of at least $50 \mathrm{~cm}$ diameter located in the vicinity of other oyster clumps with a maximum distance of $10 \mathrm{~m}$.

Main efforts in the Oosterschelde were made in 19992002. In 2003 and 2005 additional contour surveys were carried out in the eastern and central areas, respectively.
Fig. 1 Oosterschelde estuary with different parts (west, central, north, east) including tidal flats and oyster culture plot area in the eastern part. In central and east the sites of experimental oyster fishery are shown: intertidal sites: $a$ and $b$, subtidal sites $c$ and $d$

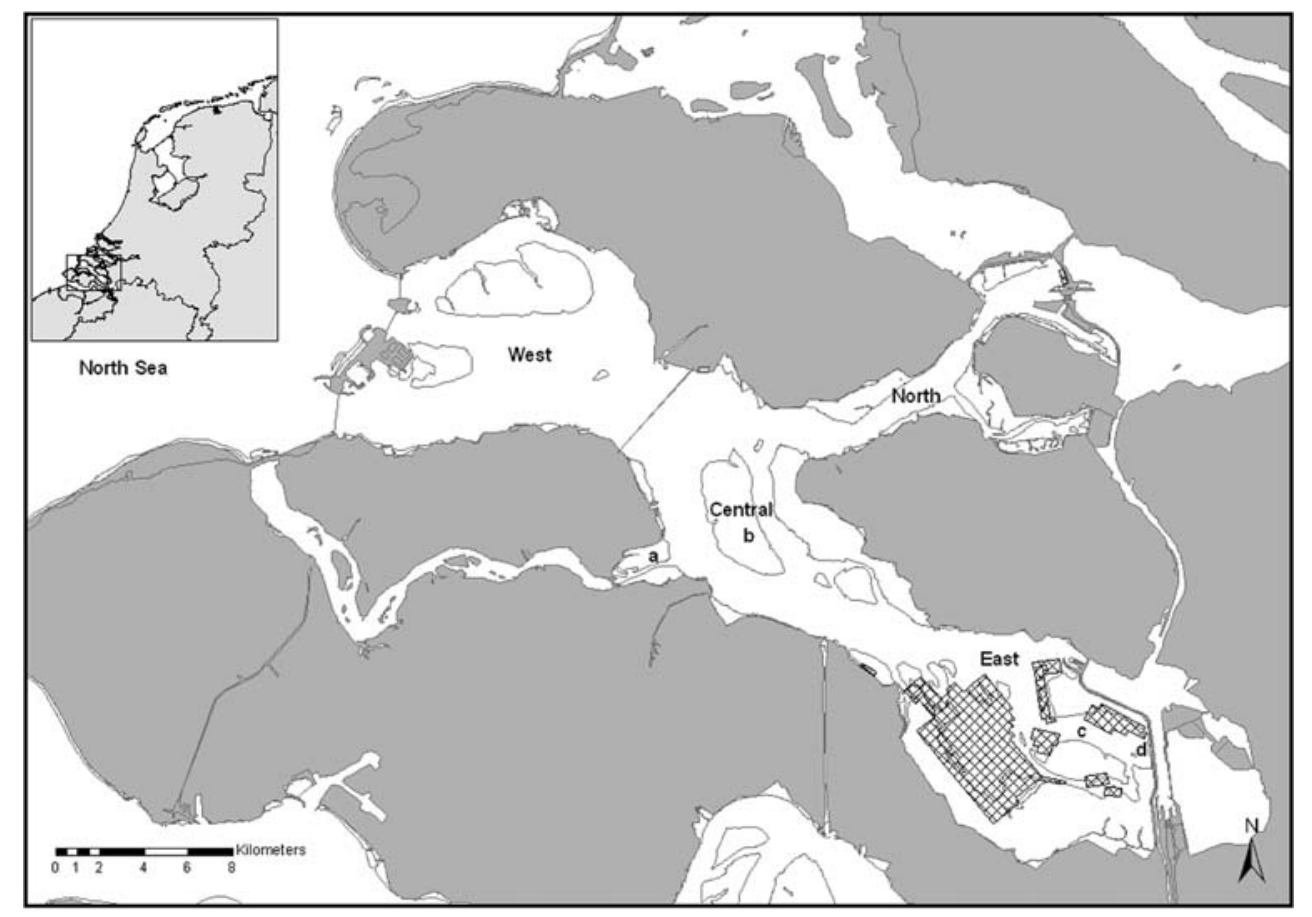




\section{Aerial photographs}

Reconstruction of the development of intertidal oyster beds was based on aerial photography of the Oosterschelde for the period 1980, 1989-1991 and 19992002. For the latter period, aerial photographs were combined with field data for ground truth. (Kater and Baars 2004).

\section{Subtidal beds}

In March 2002 a side scan sonar survey was carried out in the gullies of the Oosterschelde. Registrations were done in all gullies of the Oosterschelde. The registrations have been checked by scuba diving. In total 11 field observations by diving were carried out in 10 areas. For soft sediment, oyster beds could be identified with side scan sonar with sufficient accuracy, although no quantitative data could be derived from the first explorative survey.

\section{Coverage and biomass estimation}

During contour mapping surveys coverage of the oyster bed with oysters was estimated by using a frame of $1 \mathrm{~m}^{2}$ surface with a finer grid of rope that has 100 crosslinks. The frame was placed at random on the oyster bed and the number of crosslinks that covered an oyster was counted, giving percentage cover per $\mathrm{m}^{2}$.

Total number of oysters covered by the frame was removed, separated in live oysters and shell remains and wet weight was measured of both fractions. Part of the live samples $(15 \mathrm{~L})$ were taken to the laboratory for cooked flesh weight estimation, dry weight estimation after drying for $48 \mathrm{~h}$ at $70^{\circ} \mathrm{C}$, and ashfree dry weight estimation after ashing for $4 \mathrm{~h}$ at $520^{\circ} \mathrm{C}$.

\section{Experimental fishery sites}

In the framework of a project to test the possibilities for the removal of excessive oyster stocks, a number of oyster beds were selected in 2006 for experimental fishery and impact monitoring. In total 50 ha high density oyster beds were selected: two intertidal areas of 12.5 ha each and two subtidal areas (Fig. 1). On these beds biomass samples were taken, using a large $1.062 \mathrm{~m}^{2}$ Van Veen type grab onboard a dredging vessel. On each bed ten samples were taken and sorted out per sample; oysters were separated into live oysters and dead shell remains, and wet weight was measured of both fractions. Dry flesh weight and ash-free dry weight was estimated of the living oysters.

\section{Results}

Development of intertidal oyster bed area

Aerial photographs taken in 1980 covered about $60 \%$ of the Oosterschelde intertidal areas. In particular, areas in the eastern part were missing. The surface area of oyster beds reconstructed in the photographed area is 15 ha. The total surface area of oyster beds can be estimated by correcting for the areas not photographed, assuming a homogeneous scattering of oyster beds. On this basis the total estimated surface in 1980 is $15-35$ ha. This is probably an underestimation as the eastern part has always shown the largest bed area, apparently due to the initial introduction in this area (Fig. 2; Table 1).

In 1989-1991, 89\% of the intertidal areas were covered by aerial photographs. The surface area of reconstructed oyster beds in photographed areas is $210-236$ ha. The oyster map 2005 is made up of contours measured in the period 2000-2005, and aerial photographs of 1999 and 2000. The total surface area of the Oosterschelde covered with oyster beds is estimated as 775 ha. Figures 2, 3, 4 show the distribution of oyster beds in 1980, 1990 and 2005.

Table 1 shows the development for the various parts of the Oosterschelde. In 2005 the coverage of the estuary with oyster beds was $6.8 \%$ of the total intertidal area, in the eastern part $9.2 \%$, north $7.6 \%$, central $5.1 \%$ and west $4.8 \%$. This spatial gradient from east to west corresponds with the temporal development, given first introduction in the eastern part.

Biomass and standing stock

A pilot study in 1998 on intertidal plots in the Oosterschelde showed high density spots with a biomass up to $110 \mathrm{~kg} / \mathrm{m}^{2}$ and areas with moderate densities $\left(10-27 \mathrm{~kg} / \mathrm{m}^{2}\right)$. The fraction of live oysters was on average $60 \%$ (Table 2) (Perdon and Smaal 2000)

A detailed study was carried out in 2003 to estimate coverage and biomass on a number of tidal flats. In total ca 80 quadrats of $1 \mathrm{~m}^{2}$ were sampled and analyzed (Gelderman 2003). Table 3 shows average total weight of oysters of $32.5 \pm 24.1 \mathrm{~kg} / \mathrm{m}^{2}$, of which $38.9 \pm 12.6 \%$ were live oysters. The live oysters had an average flesh content of $5.3 \pm 1.6 \%$.

In 2006, samples were taken with a $1-\mathrm{m}^{2}$ grab on sites, pre-selected for experimental fishery (Wijsman et al. 2006). The average total oyster mass of these intertidal beds was $30.2 \mathrm{~kg} / \mathrm{m}^{2}$ of which $33 \%$ consisted of live oysters. For subtidal experimental sites total oyster mass was $24.4 \mathrm{~kg} / \mathrm{m}^{2}$ of which only $18.8 \%$ were live oysters (Table 4 ). 


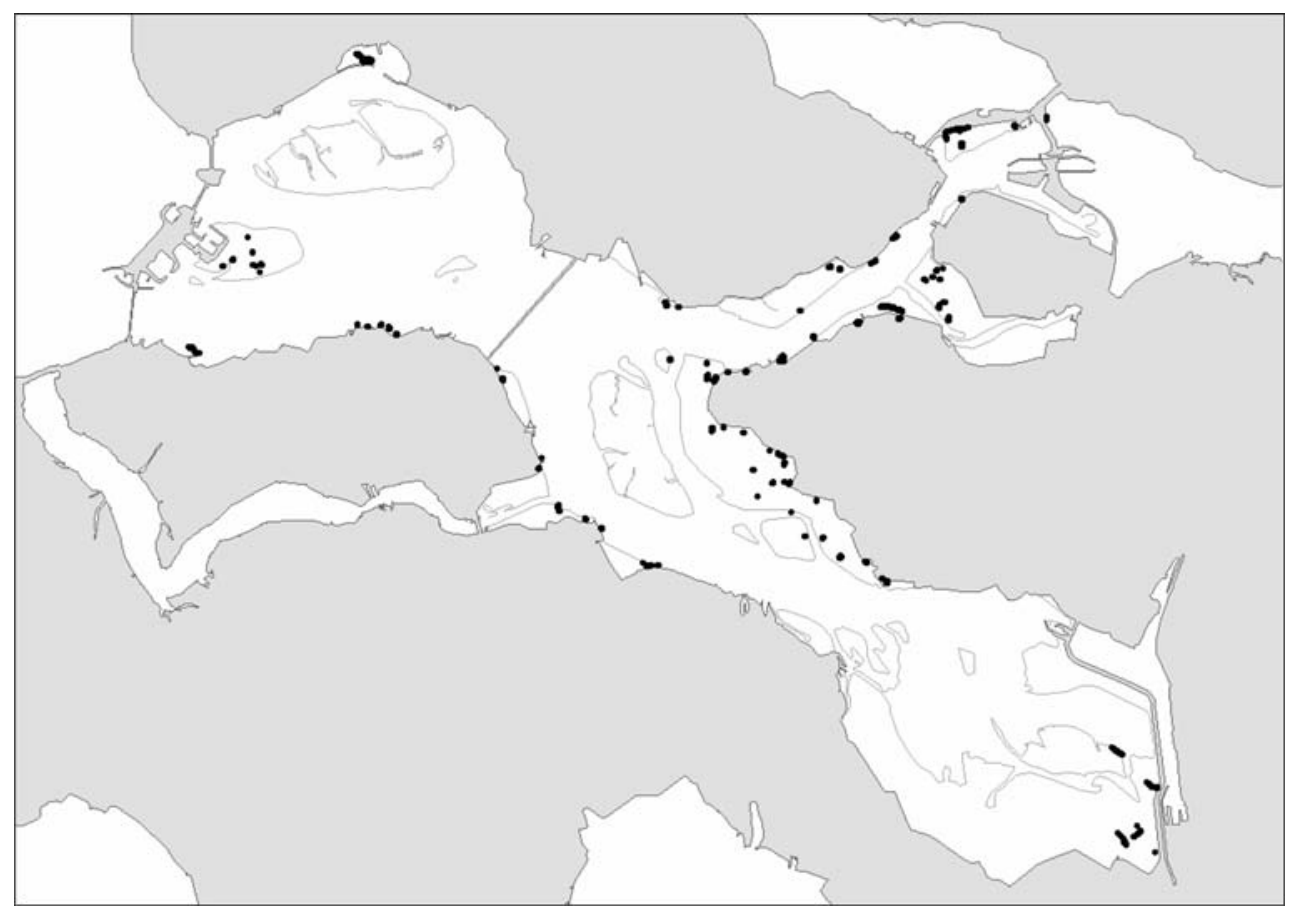

Fig. 2 Locations of littoral oyster beds in 1980 (black dots, not scaled) on the basis of aerial photography; estimated oyster bed area 15-25 ha

Table 1 Estimated intertidal oyster bed area in the different parts of the Oosterschelde

\begin{tabular}{|c|c|c|c|c|c|c|c|c|c|}
\hline & \multirow{3}{*}{$\begin{array}{l}\text { Intertidal } \\
\text { area (ha) }\end{array}$} & \multicolumn{8}{|c|}{ Oyster bed area } \\
\hline & & \multicolumn{2}{|c|}{1980} & \multicolumn{2}{|l|}{1990} & \multicolumn{2}{|l|}{2002} & \multicolumn{2}{|l|}{2005} \\
\hline & & ha & $\%$ & ha & $\%$ & ha & $\%$ & ha & $\%$ \\
\hline West & 2,389 & 4.8 & 0.20 & 21.4 & 0.90 & 91.8 & 3.84 & 114.5 & 4.79 \\
\hline Central & 3,334 & 3.3 & 0.10 & 52.6 & 1.58 & 180.8 & 5.42 & 170.5 & 5.11 \\
\hline North & 1,642 & 6 & 0.37 & 67.6 & 4.12 & 97.3 & 5.93 & 125.3 & 7.63 \\
\hline East & 4,003 & 0.7 & 0.02 & 70.8 & 1.77 & 270.1 & 6.75 & 364.9 & 9.12 \\
\hline Total & 11,368 & 14.8 & 0.13 & 212.4 & 1.87 & 640 & 5.63 & 775.2 & 6.82 \\
\hline
\end{tabular}

On the basis of contour surveys, the total wet weight in 2005 of live animals was estimated as $89.4 \mathrm{mln} \mathrm{kg}$, out of a total weight of $216.6 \mathrm{mln} \mathrm{kg}$ live + dead oysters including shells. The total stock was estimated as $1.01 \mathrm{mln} \mathrm{kg}$ ashfree dry weight (Table 5).

\section{Subtidal bed area}

A first estimate of the area of subtidal oyster beds in the gullies and along the slopes gives a figure of 700 ha where oyster beds occur. This is based on a side scan sonar survey in combination with scuba diving. In total, 1,900 ha were surveyed and oysters were observed over all water depths up to $42 \mathrm{~m}$. The approach did not allow quantification to the standing stock

\section{Discussion}

\section{Arrival and establishment}

Aerial photography of oyster beds in the Oosterschelde was evaluated by Kater and Baars (2004) and considered useful in surveying and reconstructing the development of intertidal Pacific oyster beds. They have shown that the chances of false positives (i.e., a spot located as an oyster bed without being an oyster bed, or surface areas being overestimated) were on average $2.4 \%$. It should be noted that there is a chance of underestimation. The verification with ground truth showed that in some cases more than half of the surface of oyster beds was missed on the photographs (false negatives average value 53\%). Hence the estimates should be considered as conservative.

Based on the reconstruction, it was concluded at least 25 ha of wild intertidal oyster beds had developed already in 1980. In 1990 this had expanded almost tenfold to 236 ha. The present paper shows that this figure has more than tripled to 775 ha in 2005.

These figures are consistent with the development of subtidal oysters in high densities on the artificial rocky shores in the Oosterschelde. These habitats have been surveyed in the western, central and northern part since 1985 by scuba diving, and a fast colonization by the oysters is reported. The coverage of hard bottoms in 1985 the northern part was $10 \%$ and around $1 \%$ in the west and central parts (no data of east were reported). In 2002, 
Fig. 3 Littoral oyster bed (black spots) reconstruction in 1990 , estimated surface 210 ha
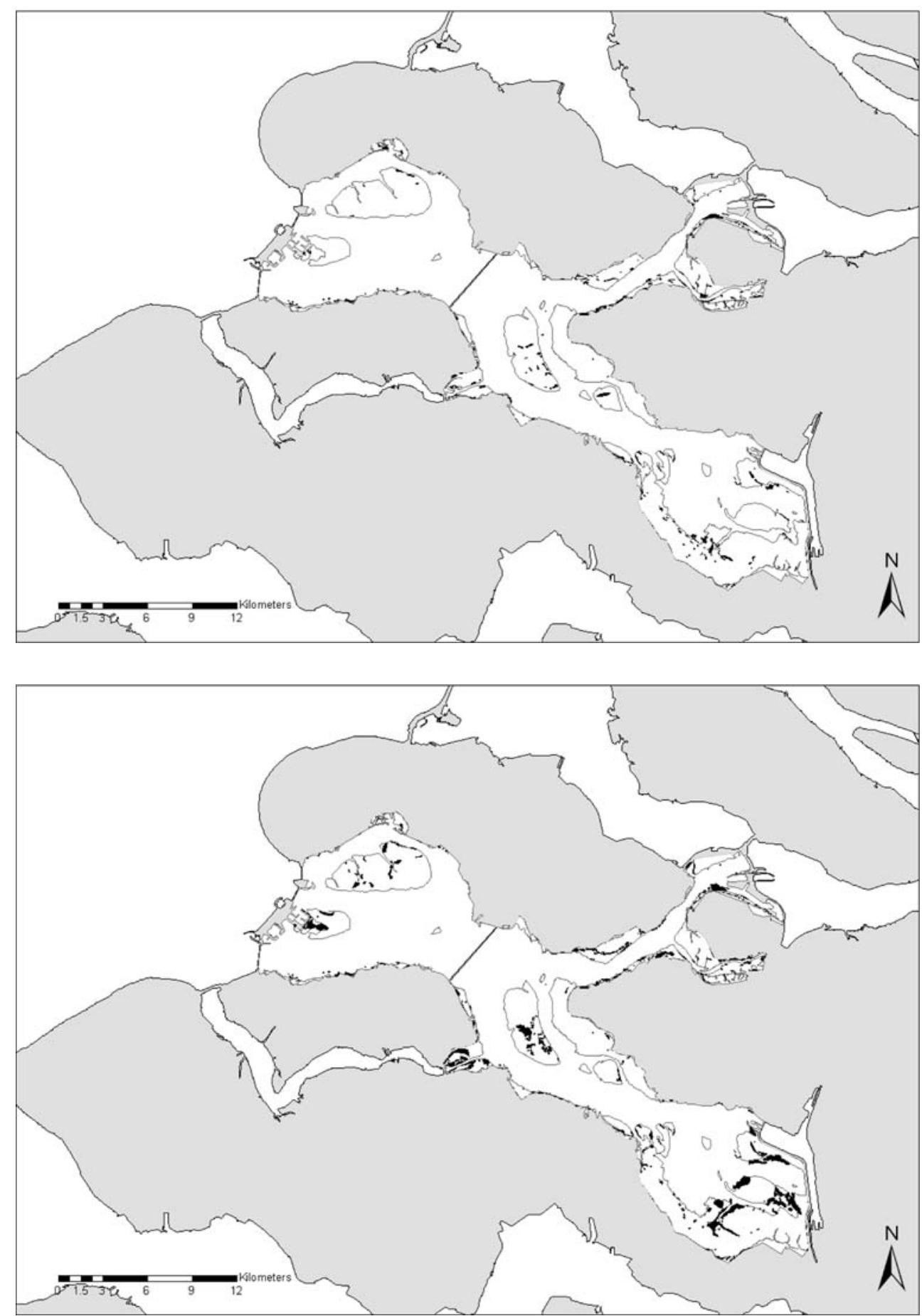

Fig. 4 Littoral oyster beds in 2005, total estimated surface 775 ha average coverage was $50-60 \%$ with maximum value of $90 \%$ in some areas in west (De Kluyver and Dubbeldam 2003).

There is also a considerable wild oyster stock in shallow areas and gullies. This stock is exploited for spat collection, fishery on juvenile oysters and recently also for the extraction of shell material. No complete quantitative survey has been accomplished yet. On the basis of a side scan sonar survey there are indications that the colonization is similar to the intertidal areas, and a preliminary estimate of 700 ha subtidal oyster beds were recorded.

The arrival phase of colonization is documented by Drinkwaard (1999a, b). He describes the introduction of two strains of spat of $1 \mathrm{~cm}$ size from British Columbia in 1964 by an oyster farmer that were in water channels of a lobster park in Yerseke, bordering the Oosterschelde (Fig. 1). After one growing season the Kumamoto (K) strain had a size of $5 \mathrm{~cm}$ and the Miyagi (M) strain $10 \mathrm{~cm}$ 
Table 2 Biomass $\left(\mathrm{kg} / \mathrm{m}^{2}\right), \%$ live oysters and \% flesh in different parts of the Oosterschelde in early spring 1998

\begin{tabular}{lllllc}
\hline 1998 & \multicolumn{2}{l}{ Biomass (dead and alive) } & & Live $\%$ & Flesh \% \\
\cline { 2 - 4 } & Avg & SD & $n$ & & \\
\hline West & 38.0 & 36.9 & 6 & 53.5 & 5.5 \\
Central & 34.8 & 43.5 & 9 & 70 & 5.6 \\
North & ND & ND & 3 & ND & 10.6 \\
East & 35.6 & 44.2 & 6 & 58 & 5.8 \\
Avg & 36.1 & 41.5 & 21 & 60.5 & 6.9 \\
\hline
\end{tabular}

length. After the following winter $96 \mathrm{~kg}$ of the $\mathrm{M}$ strain and $54 \mathrm{~kg}$ of the K strain were brought to oyster culture plot $\mathrm{nr}$ 183 of the fishery institute (RIVO), located in the eastern part of the Oosterschelde. The oysters have been harvested in October and November 1965 with a yield of $415 \mathrm{~kg} \mathrm{M}$ strain and $130 \mathrm{~kg} \mathrm{~K}$ strain (RIVO data). In 1966 further experiments were carried out with a strain from the Hiroshima area (Drinkwaard 1999a). No quantitative data have been recorded of the follow-up of these experiments. Registration of oyster landings show a first commercial harvest of Pacific oysters of ca 1,000 kg in 1976 (Drinkwaard 1999a). The arrival definitely started in 1964, but it is not clear whether this was sufficient as an onset of the establishment phase. It is likely that farmers have introduced Pacific oysters several times from various origins. In 1969 and 1970 spat from British Columbia was introduced in France followed by introduction of adult oysters as broodstock in 1971 in Marennes-Oleron and Arcachon bay (Drinkwaard 1999b). There are indications that these stocks were also a resource for Dutch oyster farmers (Wolff 2005; Gmelich-Meyling-van Hemert 2004).

Meanwhile commercial exploitation developed further. In 1988 the harvest amounted up to 1,000 tons wet weight and evolved since to an annual average yield of appr. 3,000 tons over the period 2000-2003. As the average culture cycle is 3 years and the average biomass production per unit spat is $3-5$, the stock on culture plots is estimated at 6,000 tons wet weight, based on 1,000 tons seed, 2,000 tons half-grown and 3,000 tons consumption sized oysters.
Table 4 Oyster biomass on litoral and sublitoral experimental fishing plots, before fishery in February 2006

\begin{tabular}{lllllllll}
\hline & \multicolumn{2}{l}{ Total weight } & & \multicolumn{2}{l}{ Live weight } & \multicolumn{2}{l}{ Fraction live } \\
\cline { 2 - 3 } & $\mathrm{kg} / \mathrm{m}^{2}$ & $\mathrm{SD}$ & $n$ & & $\mathrm{~kg} / \mathrm{m}^{2}$ & $\mathrm{SD}$ & $\%$ \\
\hline Intertidal 1 & 23.7 & 10.2 & 10 & & 11.9 & 5.7 & 50.4 \\
Intertidal 2 & 34.7 & 16.6 & 10 & & 8.4 & 5.2 & 24.1 \\
Avg intertidal & 29.2 & 14.6 & 20 & & 10.2 & 5.6 & 34.8 \\
Subtidal 1 & 22 & 13.2 & 10 & 4.9 & 2.8 & 22.2 \\
Subtidal 2 & 26.9 & 19.6 & 11 & & 4.1 & 3.6 & 15.0 \\
Avg subtidal & 24.6 & 16.6 & 21 & 4.5 & 3.2 & 18.2 \\
\hline
\end{tabular}

Table 5 Estimated intertidal stock size in 2005; data based on oyster bed contour mapping in the period 2003-2005 and biomass data of Table 3

\begin{tabular}{lclll}
\hline 2005 & $\begin{array}{l}\text { Total wet } \\
\text { weight } \\
(\mathrm{mln} \mathrm{kg})\end{array}$ & $\begin{array}{l}\text { Total live } \\
\text { weight } \\
(\mathrm{mln} \mathrm{kg})\end{array}$ & $\begin{array}{l}\text { Total wet } \\
\text { flesh weight } \\
(\mathrm{mln} \mathrm{kg})\end{array}$ & $\begin{array}{l}\text { Ashfree } \\
\text { dry weight } \\
(\mathrm{mln} \mathrm{kg})\end{array}$ \\
\hline West & 50.49 & 22.02 & 1.30 & 0.32 \\
Central & 45.86 & 14.58 & 0.76 & 0.19 \\
North & 38.84 & 14.49 & 0.83 & 0.21 \\
East & 81.37 & 36.29 & 1.16 & 0.29 \\
Total & 216.57 & 87.38 & 4.04 & 1.01 \\
\hline
\end{tabular}

\section{Expansion in the Oosterschelde}

The first indications of the establishment phase date from the mid seventies, as spatfall was first registered in 1975 (Drinkwaard 1999a). The following year with a 50-day period of water temperature above $20^{\circ} \mathrm{C}$ showed excessive spatfall, and can be considered as the start of the expansion phase. There are indeed clear indications that colonization is driven by recruitment, and that recruitment success is higher after warm summers (Diederich et al. 2004). As mentioned by Drinkwaard (1999a) there was excessive recruitment in 1976, 1982, and 1989 and this became more frequent in the nineties. In these years, summer water temperatures indeed were over $20^{\circ} \mathrm{C}$ for prolonged periods
Table 3 Oyster coverage and biomass on sampled squares in different parts of the Oosterschelde in February 2003 ( $n=$ number of sampled stations)

\begin{tabular}{|c|c|c|c|c|c|c|c|c|c|c|}
\hline & \multicolumn{3}{|c|}{ Coverage } & \multicolumn{3}{|c|}{ Biomass $\left(\mathrm{kg} / \mathrm{m}^{2}\right)$} & \multicolumn{2}{|c|}{ Fraction live } & \multicolumn{2}{|c|}{ Flesh content } \\
\hline & \multicolumn{3}{|c|}{$\% / \mathrm{m}^{2}$} & \multicolumn{3}{|c|}{ Total (dead and alive) } & \multicolumn{2}{|l|}{$\%$} & \multicolumn{2}{|c|}{$\%$ of live weigh } \\
\hline & Avg & $\mathrm{SD}$ & $n$ & Avg & SD & $n$ & Avg & SD & Avg & $\mathrm{SD}$ \\
\hline West & 32.5 & 19.1 & 26 & 44.1 & 26.1 & 22 & 43.6 & 9 & 5.9 & 0.8 \\
\hline Central & 26.6 & 21.6 & 18 & 26.9 & 18.9 & 18 & 31.8 & 7.6 & 5.2 & 1.1 \\
\hline North & 34.5 & 30.3 & 23 & 31 & 24.6 & 23 & 37.3 & 14.6 & 5.7 & 2 \\
\hline East & 29.6 & 24.5 & 12 & 22.3 & 9.3 & 12 & 44.6 & 12.7 & 3.2 & 0.6 \\
\hline Avg & 31.3 & 23.4 & 79 & 32.5 & 24.1 & 75 & 38.9 & 12.5 & 5.3 & 1.6 \\
\hline
\end{tabular}


(http://www.waterbase.nl). The increase of the frequency of warm summers as a possible effect of climate change will promote the further development of the Pacific oysters in Dutch coastal waters.

The total bed area of the oysters in the Oosterschelde is still increasing. Expansion of the oyster beds is limited to areas relatively low in the intertidal zone. Almost all oyster beds have developed below mid-tide level. It is furthermore noticed that oyster beds in some cases have developed in areas that have been in use as intertidal mussel culture plots until the early nineties. This is particularly observed on the tidal flat area in the central part (Fig. 5). After 1994, intertidal plots were abandoned by the mussel farmers as the government issued permits for expansion of culture plot to the more preferred subtidal areas. It is likely that the intertidal areas that were appropriate for mussel farming also are favorable for oysters and that the end of intertidal mussel culture implied the end of maintenance of the culture plots, including removal of oysters. Therefore development after 1994 may be faster than before.

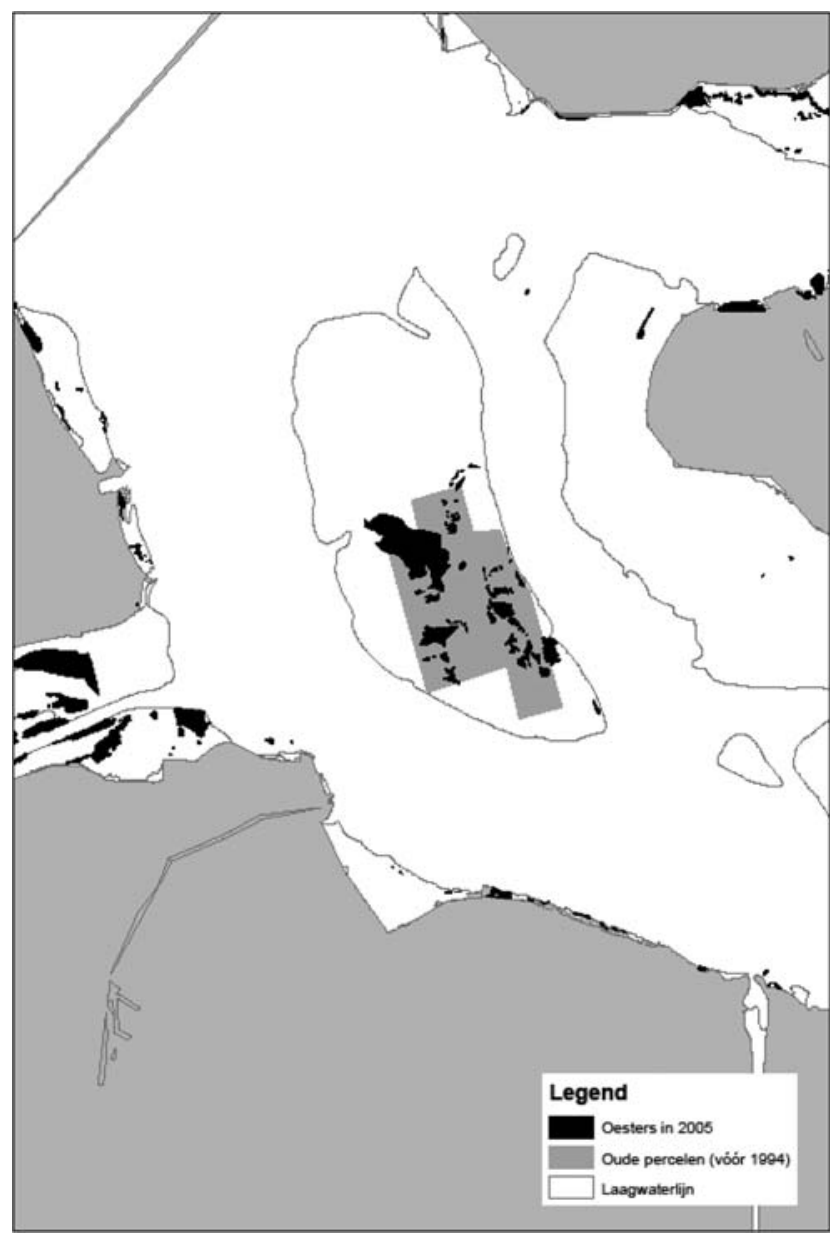

Fig. 5 Oyster bed contours and former mussel bed locations (in grey) in the central area of the Oosterschelde
Considering the oyster development for ca 40 years no signs have been recorded of serious damage to the oyster development due to climatic conditions (severe winters, warm summers), predation, or infestations. Also excessive summer mortality as occurs in France (Soletchnik et al. 2005) has not manifested. No clear external limits to the development have been identified in the Oosterschelde so far, as well as in the other colonized areas. The lower biomass in dense beds might be an indication of self-thinning, hence of adjustment to local conditions and this phenomenon needs further documentation.

Meanwhile the impacts are manifold and measures are being prepared to reduce the stock by management measures. Novel observations show larviphagy of various shellfish larvae by the oysters, while oyster larvae may escape from filtration (Troost et al. 2008). As hypothesized by Smaal et al. (2005), reef-building species have more resistance in comparison to infaunal species that show a more resilient response. As a consequence an invasive ecoengineering species that is relatively resistant to environmental stress may induce structural changes in the ecosystem. The oyster as a reef builder typically shows this type of response.

It results in a strong competition between the wild oysters and the other filter feeders. Growth rates and flesh content of commercially exploited mussels, cockles and oysters in the Oosterschelde estuary are decreasing and the major questions are as to how far the wild oysters are impacting the carrying capacity of the system, and as to how far largescale removal of the oysters is an effective measure to maintain various nature and production functions of the estuary (Wijsman and Smaal, in prep).

\section{Expansion to other areas}

The expansion of Pacific oysters in The Netherlands is not limited to the Oosterschelde (see Wolff 2005). Already in 1987, spatfall was observed in the saline lake Grevelingen, a former estuary just north of the Oosterschelde (Drinkwaard 1999a). Also Pacific oysters have been recorded in the Westerschelde estuary and along the North Sea coast. Just recently the observation was reported that Pacific oysters have settled in the ports of Amsterdam (Parool newspaper, 28 Dec 2007).

Introduction in the Wadden Sea has not yet been clearly documented. It could be the result of larval transport from the Oosterschelde with the residual current in northern direction (Drinkwaard 1999a; Smaal et al. 2005) or occasional transport by mussel boats that fish in both Oosterschelde and Wadden Sea. However, it is more likely that introduction occurred in 1978 when the RIVO facilities on Texel were used for the culture of flat oyster spat from a French hatchery. This spat turned out to be mixed with 
juveniles of Pacific oysters that showed rapid growth. Larger specimen were brought to the outlet basin of the desalinization plant at Oudeschild, where water temperatures were elevated (J. Bol, pers comm.). From this nursery system expansion in the Wadden Sea may have started. Indeed, in 1983 first records of wild oysters were documented near Oudeschild, a spot in the Wadden Sea close to the outlet of the basin close (Bruins 1983; Drinkwaard 1999a; Wolff 2005).

Further expansion in the Dutch Wadden Sea is described in Tydeman (1999), Dankers et al. (2004), Wolff (2005) and Smaal et al. (2005). During the annual shellfish survey in the Dutch Wadden Sea in 2006 oysters were observed in densities $>0.2 \mathrm{~kg} / \mathrm{m}^{2}$ on $5 \%$ of 1,415 sampled intertidal stations. On the basis of this survey and an extrapolation of earlier survey results, the oyster bed area was estimated at $323 \mathrm{ha}$, while mixed beds of oysters with mussels occupied 376 ha. The total intertidal area with Pacific oysters is thus about 800 ha. The standing stock was estimated at $20.5 \mathrm{mln} \mathrm{kg}$ fresh weight on the basis of weight estimates at the sampled stations (Goudswaard et al. 2007). Results of subtidal surveys for mussel seed also show occurrence of wild-oyster beds of several hundreds of hectares (Van Stralen, pers comm.)

The 800 ha intertidal area covered with oysters in the Wadden Sea is $0.64 \%$ of the total tidal flat area, compared to $7 \%$ in the Oosterschelde; the standing stock is more than 30 times lower per unit area than in the Oosterschelde. The Wadden Sea development shows arrival and establishment until the end of the 1990s and an expansion phase that may have started in the period 1995-2003 (Wolff 2005).

\section{Adjustment}

Biomass data show a decrease in the fraction live oysters in the Oosterschelde. In 1998, up to $60 \%$ was alive while in 2003 this was $39 \%$, and on the experimental sites in 2006 the fraction of live oysters was on average $33 \%$ on the intertidal sites. Total biomass was maintained at approximately $30 \mathrm{~kg} / \mathrm{m}^{2}$.

The decrease in the fraction of live oysters might be an indication of adjustment of the oysters to the local conditions.

\section{Conclusions}

In conclusion, the introductions of the Pacific oyster in 1964-1970 have resulted in invasion of the Oosterschelde estuary that is still in progress. From the Oosterschelde, proliferation has occurred to the adjacent water bodies and is now expanding to the North. Warmer summers will stimulate further expansion of the oysters in areas that have already been colonized, as well as in new areas. For existing functions of coastal waters such as for shellfish culture and also as feeding areas for shellfish-eating birds this can be a serious threat. However, oyster reefs can also provide an important habitat for specific species.

The fraction of live oysters in the Oosterschelde seems to decrease, and this may indicate adjustment of the oysters to local conditions. Meanwhile, total bed area is still increasing. We hypothesize that on high-density spots the oyster development now shows signs of adjustment to local conditions in the Oosterschelde, while the population is still able to expand.

Acknowledgments The authors would like to thank Jack Perdon, Emiel Brummelhuis and the crew of the Schollevaar and the RIOS for assistance in the field, and TNO-NITG for the side scan sonar survey. Dr N. Dankers and three anonymous reviewers are acknowledged for valuable complementary remarks and critical comments on the manuscript.

Open Access This article is distributed under the terms of the Creative Commons Attribution Noncommercial License which permits any noncommercial use, distribution, and reproduction in any medium, provided the original author(s) and source are credited.

\section{References}

Bruins RBW (1983) Crassostrea gigas op Texel. Corresp Blad Ned Malacol Ver 215:1436-1438 (in Dutch)

CWSS (Common Wadden Sea Secretariat) (2007) TMAP manualthe trilateral monitoring and assessment program. CWSS, Wilhelmshafen

Dankers NMJA, Dijkman EM, Jong ML, de Kort G, de Meijboom A (2004) De verspreiding en uitbreiding van de Japanse oester in de Nederlandse Waddenzee. Alterra rapport 909, p 51 (in Dutch)

De Kluyver M, Dubbeldam M (2003) De sublitorale hard-substraat gemeenschappen in de Oosterschelde, evaluatie van de ontwikkelingen in de periode 1985-2002. Aquasense, p 107 (in Dutch)

Drinkwaard AC (1999a) Introductions and developments of oysters in the North Sea area: a review. Helgoländer Meeresunters 52:301308

Drinkwaard AC (1999b) History of cupped oyster in European coastal waters. Aquac Eur 24(1):7-11

Diederich S, Nehls G, van Beusekom JEE, Reise K (2004) Introduced pacific oysters (Crassostrea gigas), in the Northern Wadden Sea: invasion accelerated by warm summers? Helgol Mar Res 59:97-106

Gelderman E (2003) Oestersurvey 2003: onderzoek naar de bestandsgrootte van de Japanse oester in de Oosterschelde. RIVO Yerseke (in Dutch)

Goudswaard K, Kesteloo JJ, van Stralen MR (2007) Het bestand aan Japanse Oesters in het litoraal van Nederlands deel van de Waddenzee in 2004-2006. Imares C012/07 (in Dutch)

Gmelich-Meyling-van Hemert G (2004) Vissen op Zeeuws water. Den Boer \& de Ruiter, Vlissingen, p 192 (in Dutch)

Kater B, Baars D (2004) The potential of aerial photography for estimating surface areas of intertidal pacific oyster beds (Crassostrea gigas). J Shellfish Res 23(3):773-779

Nehls G, Diederich S, Thieltges DW, Strasser M (2006) Wadden Sea mussel beds invaded by oysters and slipper limpets: competition or climate control? Helgol Mar Res 60:135-143

Nienhuis PH, Smaal AC (1994) The Oosterschelde estuary, a casestudy of a changing ecosystem: an introduction. Hydrobiologia 282(283):1-14 
Perdon J, Smaal AC (2000) Het bestand aan Japanse oesters op de platen van de Oosterschelde. RIVO Yerseke C030/00 (in Dutch)

Reise K (1998) Pacific oysters invade mussel beds in the European Wadden Sea. Senckenb Marit 28:167-175

Reise K, Olenin S, Thieltges DW (2006) Are aliens threatening European aquatic coastal ecosystems? Helgol Mar Res 60:77-83

Smaal A, van Stralen M, Craeymeersch J (2005) Does the introduction of the Pacific oyster Crassostrea gigas lead to species shifts in the Wadden Sea? In: Dame RF, Olenin S (eds) The comparative role of suspension-feeders in ecosystems. Springer, Berlin, pp $277-$ 289

Soletchnik P, Lambert C, Costil K (2005) Summer mortality of Crassostrea gigas in relation to environmental rearing conditions. J Shellfish Res 24:197-207

Troost K, Veldhuizen R, Stamhuis EJ, Wolff WJ (2008) Can bivalve veligers escape feeding currents of adult bivalves? JEMBE $358: 185-196$
Tydeman P (1999) Japanse oesters in de Eemshaven. Het Zeepaard 59(2):58-64 (in Dutch)

Wehrmann A, Herlyn M, Bungenstock F, Hertweck G, Millat G (2000) The distribution gap is closed-first records of naturally settled Pacific oysters Crassostrea gigas in the East Frisian Wadden Sea, North Sea. Senckenb Marit 30:153-160

Wolff WJ (2005) Non-indigenous marine and estuarine species in the Netherlands. Zool Med Leiden 79(1):1-116

Wijsman J, van Stralen M, Dubbeldam M, Geene R, de Kluijver M, van Zanten E, Smaal AC (2006) Wegvisproef Japanse oesters in de Oosterschelde, tussentijdse rapportage. RIVO rapport C077/06 (in Dutch) 